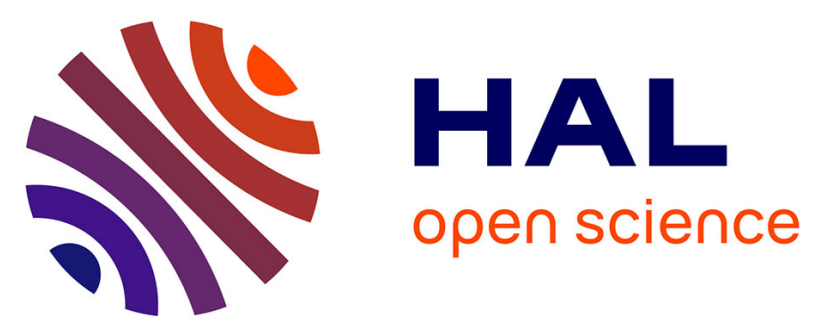

\title{
Upgrading of furfural to biofuel precursors via aldol condensation with acetone over magnesium hydroxide fluorides $\mathrm{MgF} 2-\mathrm{x}(\mathrm{OH}) \mathrm{x}$
}

Minrui Xu, Stephane Celerier, Jean-Dominique Comparot, Julie Rousseau, Matthieu Corbet, Frederic Richard, Jean-Marc Clacens

\section{To cite this version:}

Minrui Xu, Stephane Celerier, Jean-Dominique Comparot, Julie Rousseau, Matthieu Corbet, et al.. Upgrading of furfural to biofuel precursors via aldol condensation with acetone over magnesium hydroxide fluorides MgF 2-x (OH)x. Catalysis Science \& Technology, 2019, 9 (20), pp.5793-5802. 10.1039/C9CY01259A . hal-02325058

\section{HAL Id: hal-02325058 \\ https://hal.science/hal-02325058}

Submitted on 22 Oct 2019

HAL is a multi-disciplinary open access archive for the deposit and dissemination of scientific research documents, whether they are published or not. The documents may come from teaching and research institutions in France or abroad, or from public or private research centers.
L'archive ouverte pluridisciplinaire HAL, est destinée au dépôt et à la diffusion de documents scientifiques de niveau recherche, publiés ou non, émanant des établissements d'enseignement et de recherche français ou étrangers, des laboratoires publics ou privés. 


\title{
Upgrading of furfural to biofuel precursors via aldol condensation with acetone over magnesium hydroxide fluorides $\operatorname{MgF}_{2-x}(\mathrm{OH})_{x}$
}

Received 00th January 20xx, Accepted 00th January 20xx DOI: $10.1039 / \times 0 \times x 00000 x$

\author{
Minrui $\mathrm{Xu}{ }^{\mathrm{a}}$, Stéphane Célerier ${ }^{*}{ }^{\mathrm{a}}$, Jean-Dominique Comparot ${ }^{\mathrm{a}}$, Julie Rousseau ${ }^{\mathrm{a}}$, Matthieu Corbet \\ ${ }^{\mathrm{b}}$, Frédéric Richard ${ }^{*}$, Jean-Marc Clacens ${ }^{\mathrm{a}}$
}

\begin{abstract}
Wastes from ligno-cellulosic material, especially hemicellulose, are extremely promising resources to produce fuels from renewable raw materials. Furfural, resulting from the depolymerization of hemicellulose, is often considered as an extremely interesting platform molecule. Particularly, new biofuels containing molecules with 8 and 13 carbon atoms can be produced from aldol condensation of furfural and acetone followed by a deoxygenation reaction. In this work, several magnesium hydroxide fluorides $\mathrm{MgF}_{2-x}(\mathrm{OH})_{x}$ were prepared by a sol-gel method with various $\mathrm{F} / \mathrm{Mg}$ ratios $(0$ to 2$)$ at $100{ }^{\circ} \mathrm{C}$. All solid samples were fully characterized by several technics (nitrogen adsortion-desorption, TEM, IR, XRD and ICP). $\mathrm{MgF}_{2}$. ${ }_{x}(\mathrm{OH})_{x}$ were mainly composed of an intimate mixture of $\mathrm{MgF}_{2}$ and $\mathrm{Mg}(\mathrm{OH})_{2-x}\left(\mathrm{OCH}_{3}\right)_{x}$ and exhibited both acid-base properties and high surface area. From $\mathrm{CO}_{2}$ adsorption experiments, a basicity scale corresponding to basic sites with moderate strength was established: $\mathrm{MgF}_{1.5}(\mathrm{OH})_{0.5}>\mathrm{MgF}(\mathrm{OH}) \sim \mathrm{MgF}_{1.75}(\mathrm{OH})_{0.25}>\mathrm{MgF}_{0.5}(\mathrm{OH})_{1.5}>\mathrm{Mg}(\mathrm{OH})_{2}>\mathrm{MgF}_{2}$. It was proposed that the presence of fluorine allowed to stabilize the basic sites with moderate strength at ambient atmosphere. The aldol condensation of furfural and acetone was carried out under mild reaction conditions $\left(50^{\circ} \mathrm{C}, \mathrm{P}_{\mathrm{atm}}\right)$ over $\mathrm{MgF}_{2}$. ${ }_{x}(\mathrm{OH})_{x}$. These catalysts were involved in this reaction without using classical activation step for basic solid catalysts, which constitutes a major advantage for energy saving and thus, economical efficiency. The solid with the F/Mg ratio equal to 1.5 $\left(\mathrm{MgF}_{1.5}(\mathrm{OH})_{0.5}\right)$ exhibited the highest activity, the furanic dimer (1,5-di(furan-2-yl)penta-1,4-dien-3-one) being the main product. A good correlation between the catalytic activity and the basicity scale was highlighted. Based on these results, the nature of active sites was proposed: a combination of a Lewis acid site (coordinatively unsaturated metal site) in the vicinity of a basic site (hydroxyl groups of $\mathrm{Mg}(\mathrm{OH})_{2-x}\left(\mathrm{OCH}_{3}\right)_{x}$ ). The effect of the furfural/acetone ratio on the catalytic $\begin{array}{lllll}\text { properties } & \text { of } & \mathrm{MgF}_{1.5}(\mathrm{OH})_{0.5} & \text { was } & \text { also }\end{array}$
\end{abstract}

\section{Introduction}

Nowadays environment-friendly development arouses more and more attention to the public. For instance, extensive efforts are made to replace petroleum resources by renewable biomassderived chemicals. ${ }^{1,2}$ Among the main components of agricultural wastes, lignocellulose remains the most abundant biomass. ${ }^{3}$ Hemicellulose, representing about $25 \%$ of lignocellulose, can be considered as a precursor of furfural, a promising biomass-derived platform molecule, mainly obtained by acid-catalyzed dehydration of xylose. $^{4-6}$

Since the research of bio-based building block synthesis from furfural continues to burgeon, multifarious value-added compounds were produced from furfural. ${ }^{7-11}$ The synthesis of new types of biofuels can also be considered from furfural, involving aldol

a. Institut de Chimie des Milieux et Matériaux de Poitiers, UMR 7285 Université de Poitiers - CNRS, 4 rue Michel Brunet, BP633, 86022 Poitiers Cedex, France. E-mail : stephane.celerier@univ-poitiers.fr, frederic.richard@univ-poitiers.fr

b. Solvay Research \& Innovation center of Lyon, 85 rue des Frères Perret, BP 62 69192, Saint Fons, France

Electronic Supplementary Information (ESI) available: [details of any supplementary information available should be included here]. See DOI: $10.1039 / x 0 x x 00000 x$ condensation and hydrodeoxygenation reactions. ${ }^{12-16}$ Aldol condensation reactions play a crucial role in the upgrading of furfural since this approach increases the carbon chain length by forming new C-C bonds. Especially, the aldol condensation of furfural and acetone leads to products containing either 8 (4-(furan2-yl)but-3-en-2-one, FAc) or 13 carbon atoms (1,5-di(furan-2yl)penta-1,4-dien-3-one, $\left.F_{2} A c\right)$, as described in scheme $1 .^{11}$ In addition, their hydrodeoxygenation were studied over metallic based catalysts to upgrade these compounds as renewable fuels. ${ }^{17-}$ 20

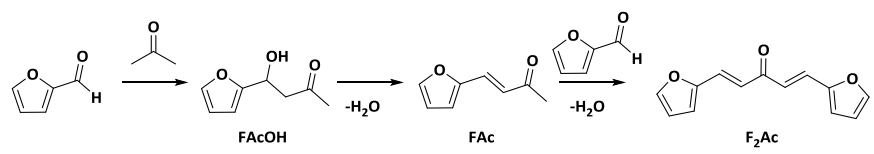
Scheme 1: Schematic illustration of adol condensation between furfural and
acetone

Generally, sodium hydroxide is a well-known homogeneous basic catalyst for aldol condensation. For example, Fakhfakh et al. ${ }^{21}$ obtained a mixture containing $\mathrm{FAc}$ and $\mathrm{F}_{2} \mathrm{Ac}$ in equimolar amounts when a total conversion of furfural was reached under mild experimental conditions $\left(40{ }^{\circ} \mathrm{C}\right.$, atmospheric pressure). 
Nevertheless, the use of such catalyst leads to many drawbacks, especially due to its high corrosiveness. In addition, homogeneous catalytic processes commonly encounter disadvantages, including the neutralization of reaction mixture producing wastes and the difficulty of catalysts separation. This reaction was also studied over solid catalysts possessing basic properties such as metal oxides. ${ }^{22-25}$ For example, Shen et al. ${ }^{22}$ obtained a high conversion of furfural (90\%) with a selectivity on furanic dimer $\left(\mathrm{F}_{2} \mathrm{Ac}\right)$ close to $65 \%$ over $\mathrm{MgO}-\mathrm{ZrO}_{2}$ in presence of a furfural/acetone molar ratio equal to 1 under drastic experimental conditions $\left(120^{\circ} \mathrm{C}\right.$ and $\left.5.2 \mathrm{MPa}\right)$. Under milder conditions $\left(60^{\circ} \mathrm{C}\right.$, atmospheric pressure) and in presence of an excess of acetone (furfural/acetone molar ratio close to 0.1 ), a high conversion of furfural (about 70\%) was also reached over $\mathrm{MgO}-\mathrm{ZrO}_{2}$ mixed oxide catalysts. ${ }^{23}$ The alcohol intermediate (4(furan-2-yl)-4-hydroxybutan-2-one, $\mathrm{FACOH}$ ) was always the main product, whereas the selectivity of $F_{2} A c$ was always less than 10 mol\%, irrespective to the furfural conversion. Over the same type of catalyst at $50{ }^{\circ} \mathrm{C}$ but under nitrogen pressure (1 MPa), a conversion of furfural close to $80 \%$ was obtained by using an equimolar mixture of acetone and furfural. ${ }^{24}$ In this case, the reaction mixture was mainly composed by $\mathrm{F}_{2} \mathrm{Ac}$ ( $75 \mathrm{~mol} \%$ in selectivity). In presence of a mesoporous $\mathrm{TiO}_{2}$ catalyst exhibiting both basic and acid sites, a low conversion of furfural was obtained $(25 \%)$ at $50{ }^{\circ} \mathrm{C} .{ }^{25}$ Probably due to the high amount of acetone compared to furfural (furfural/acetone ratio equal to 0.2 ), the monomer (FAc) was the main detected product, its selectivity being higher than $70 \mathrm{~mol} \%$. In this case, the alcohol intermediate $(\mathrm{FACOH})$ was observed in traces due to the presence of acid sites favouring its dehydration in FAc. Due to this, solids having acidic properties were also evaluated as catalysts for this reaction, such as zeolites, ${ }^{26,27}$ acids metal chlorides $^{28}$ and metal-organic frameworks. ${ }^{29,30}$ For instance, a HBEA zeolite was used as catalyst for aldol condensation of furfural and acetone even if the furfural conversion was only $38 \%$ at $100{ }^{\circ} \mathrm{C}$ (furfural/acetone molar ratio equal to 0.1 ) as shown by Kikhtyanin et al. ${ }^{26}$ Under these experimental conditions, as discussed above, an excess of acetone and the presence of acid sites explained that FAC was the main product detected in the reaction mixture. Nevertheless, an undesired reaction between two molecules of $\mathrm{F}_{2} \mathrm{Ac}$ leading to a heavy product, noted $(\mathrm{FAc})_{2}$, was observed due to the presence of Brønsted acid sites. When $S n$ was added in the HBEA zeolite in order to promote its Lewis acidity, a very high furfural conversion (more than 90\%) was reached at $160{ }^{\circ} \mathrm{C}$ (furfural/acetone molar ratio equal to 0.1). ${ }^{27} \mathrm{FAc}$ was the main product and the presence of $(\mathrm{FAC})_{2}$ was not mentioned. Interestingly, when acidic catalysts were used, the monomer (FAC) was always much more favored than the dimer $\left(F_{2} A c\right) .{ }^{26-30}$ As a consequence, in order to favor the $\mathrm{C} 13$ furanic dimer $\left(\mathrm{F}_{2} \mathrm{Ac}\right)$ instead of $\mathrm{FAc}$, during the aldol condensation of furfural and acetone, the use of basic catalysts seems to be more appropriate.

In the past decade, inorganic oxide hydroxide fluorides with high specific surface area prepared by soft chemistry were developed as a new and performant class of catalyst and/or (active) support. ${ }^{31,32}$ Such solids are known to exhibit different types of acid-base properties. As an example, aluminium hydroxide fluorides $\mathrm{AlF}_{3}$ ${ }_{x}(\mathrm{OH})_{x}$ exhibit tuneable acid properties, with neighbouring Lewis and Brønsted acid sites. These fluorides were successfully used as catalyst for acylation of 2-methylfuran by acetic anhydride $\left(50{ }^{\circ} \mathrm{C}\right.$, atmospheric pressure $)^{33}$ and for condensation of 2,3,6trimethylhydroquinione with isophytol $\left(100{ }^{\circ} \mathrm{C}\right.$, atmospheric pressure). ${ }^{34}$ On the contrary, magnesium oxide (hydroxide) fluorides $\mathrm{MgF}_{2-x}(\mathrm{OH})_{x}$ possess basic properties. Such solids were successfully used as either basic catalysts for the Michael addition of 2-methylcyclohexane-1,3-dione to methyl vinyl ketone $\left(25{ }^{\circ} \mathrm{C}\right.$, atmospheric pressure) $)^{35}$ or catalytic support. ${ }^{36-40}$ Moreover, the use of solid basic catalysts involves generally an activation step at high temperature to active basic sites by removal of carbonate species. Find an active catalyst which does not require this activation step could be interesting for energy saving and economic point of view when the reaction is performed at low temperature.

In this work, various hydroxide fluorides $\mathrm{MgF}_{2-x}(\mathrm{OH})_{x}$ solid samples with different $\mathrm{F} / \mathrm{Mg}$ ratio were prepared by a sol-gel method according to the procedure developed by Scholz et al. ${ }^{41}$. The easy control of the $\mathrm{F} / \mathrm{Mg}$ ratio of these materials allows to fine tune their acid-base properties. These solid materials were evaluated as catalyst without preliminary thermal activation for aldol condensation of furfural and acetone under mild conditions $\left(50{ }^{\circ} \mathrm{C}\right.$, atmospheric pressure) in a batch reactor. Based on these results, the nature of active sites was discussed and a reaction mechanism was proposed.

\section{Experimental}

\section{Synthesis of catalysts}

The magnesium hydroxide fluorides $\mathrm{MgF}_{2-\mathrm{x}}(\mathrm{OH})_{\mathrm{x}}$ with $\mathrm{x}=2,1.5,1$, $0.5,0.25$ and 0 were prepared by a sol-gel method, partly based on the work of Scholz et al. ${ }^{41}$ In the first step, magnesium metal (3.23 $\mathrm{g}$, Aldrich, 99.98\%) was treated with methanol in excess $(100 \mathrm{~mL}$, Sigma-Aldrich, 99.8\%) under reflux conditions for $6 \mathrm{~h}$ to form a $\mathrm{Mg}\left(\mathrm{OCH}_{3}\right)_{2}$ metal alkoxide solution. Various volumes of aqueous $\mathrm{HF}$ (48 wt\% HF in water, Sigma-Aldrich, 99.99\%) were added progressively under stirring conditions to obtain several $\mathrm{HF} / \mathrm{Mg}$ molar ratios, ranging from 0.5 to 2 . The amount of water (provided from aqueous $\mathrm{HF}$ or/and additional water) was adjusted to obtain in each case a $\mathrm{H}_{2} \mathrm{O} / \mathrm{Mg}$ ratio of 2 to favor the hydrolysis of remaining $\mathrm{OCH}_{3}$ groups. A highly exothermic reaction occurred to obtain a sol. This sol was stirred for $24 \mathrm{~h}$, aged at ambient temperature for $24 \mathrm{~h}$ and dried at $100{ }^{\circ} \mathrm{C}$ for $24 \mathrm{~h}$. According to this synthesis procedure, five solids named $\mathrm{MgF}_{2}, \mathrm{MgF}_{1.75}(\mathrm{OH})_{0.25}, \mathrm{MgF}_{1.5}(\mathrm{OH})_{0.5}, \mathrm{MgF}(\mathrm{OH})$ and $\mathrm{MgF}_{0.5}(\mathrm{OH})_{1.5}$ were obtained with the initial $\mathrm{HF} / \mathrm{Mg}$ molar ratio of 2, $1.75,1.5,1$ and 0.5 , respectively. To synthesize the sample named $\mathrm{Mg}(\mathrm{OH})_{2}$, the protocol was the same except that the aqueous $\mathrm{HF}$ solution was replaced by water (initial $\mathrm{H}_{2} \mathrm{O} / \mathrm{Mg}$ molar ratio equal to 2.5).

\section{Catalyst characterizations}


The magnesium composition of each catalyst was determined by inductively coupled plasma optical emission spectrometry (ICP-OES) using a PerkinElmer Optima 2000DV instrument. The fluorine content was measured by ionic chromatography (DIONEX ICS-2000).

X-ray diffraction (XRD) patterns were collected between $2 \theta=5$ and $75^{\circ}$ using a PANalytical EMPYREAN powder diffractometer using $\mathrm{Cu}-$ Ka monochromatized radiation source ( $K \alpha=1.54059 \AA$ ) with a $0.1^{\circ}$ step and 600 s dwell time. Phase identification was performed by comparison with the ICDS database reference files.

The textural properties were determined from $\mathrm{N}_{2}$ adsorptiondesorption isotherms, which were measured using a TRISTAR 3000 gas adsorption system at $-196{ }^{\circ} \mathrm{C}$. Prior to $\mathrm{N}_{2}$ adsorption, the samples were degassed overnight under secondary vacuum at 90 ${ }^{\circ} \mathrm{C}$. The specific surface area $\left(\mathrm{S}_{\mathrm{BET}}\right.$ in $\left.\mathrm{m}^{2} \mathrm{~g}^{-1}\right)$ was calculated from the adsorption isotherm $\left(P / P_{0}\right.$ between 0.05 and 0.20$)$ using the Brunauer-Emmett-Teller (BET) method. The total pore volume was calculated from the adsorbed volume of nitrogen at $\mathrm{P} / \mathrm{P}_{0}$ equal to 0.99. The average mesopore-size distribution was calculated from the desorption isotherm branch using the Barret-Joyner-Halenda (BJH) method.

The measurement of the basicity was obtained by adsorption of $\mathrm{CO}_{2}$ followed by FTIR spectroscopy using a ThermoNicolet NEXUS 5700 spectrometer (resolution of $2 \mathrm{~cm}^{-1}$ and 128 scans per spectrum). Solid samples were pressed into thin pellets (15-30 mg) with diameter of $16 \mathrm{~mm}$ under a pressure of $1-2 \mathrm{t} \mathrm{cm}^{-2}$ and activated in situ during two hours under secondary vacuum $\left(210^{-6} \mathrm{bar}\right)$ at $90^{\circ} \mathrm{C}$. After cooling down the samples until room temperature, $\mathrm{CO}_{2}$ was introduced in the cell, which was placed under vacuum and heated at $50{ }^{\circ} \mathrm{C}$ to remove physisorbed $\mathrm{CO}_{2}$. Finally, $\mathrm{IR}$ spectrum was recorded and normalized at the same mass for each sample. The measurement of the acidity of all solid samples was obtained by adsorption of $\mathrm{CO}$ followed by FTIR spectroscopy. Experiments were carried out with the same equipment and the same activation procedure $\left(90^{\circ} \mathrm{C}\right)$ such as those used for $\mathrm{CO}_{2}$ adsorption experiments. The cell was cooled down with liquid nitrogen to -173 ${ }^{\circ} \mathrm{C}$. Then successive doses of $\mathrm{CO}$ were introduced quantitatively and a spectrum was recorded after each adsorption until saturation. The final spectrum was recorded with 1 Torr of $\mathrm{CO}$ at equilibrium pressure (saturation). All spectra were normalized at the same mass of magnesium hydroxide fluoride samples $(20 \mathrm{mg}$ ).

Transmission Electronic Microscopy (TEM) experiments were carried out using a JEOL 2100 instrument (operated at $200 \mathrm{kV}$ with a LaB6 source and equipped with a Gatan Ultra scan camera) coupled with an Energy Dispersive X-ray Spectrometer (EDS) allowing the determination of $\mathrm{F}, \mathrm{O}, \mathrm{C}$ and $\mathrm{Mg}$ contents. For EDS measurements, 10-15 analyses were performed for each studied samples $\left(\mathrm{MgF}_{2}\right.$, $\mathrm{Mg}(\mathrm{OH})_{2}$ and $\mathrm{MgF}(\mathrm{OH})$ ) to obtain an average value. SAED (Selected area electron diffraction) experiments were also performed.

Catalytic procedure for aldol condensation of furfural and acetone
The reaction was carried out in a batch reactor fitted with a magnet stirrer and heated at $50{ }^{\circ} \mathrm{C}$. The catalyst $(200 \mathrm{mg}$ ) was introduced in a mixture composed of furfural $(5 \mathrm{mmol}$, Sigma-Aldrich, $99 \%$, preliminarily distilled), acetone $(10 \mathrm{mmol}, 5 \mathrm{mmol}$ or $2.5 \mathrm{mmol}$, Sigma-Aldrich, $>99 \%)$, heptane $(7.5 \mathrm{mmol}$, Sigma-Aldrich, $99 \%)$ and 2-methyltetrahydrofuran as solvent (5 mL, Alfa Aesar, 99\%). Heptane, inert in these conditions, was used as an internal standard for quantitative analysis carried out by Gas Chromatography. Each liquid sample obtained after various reaction times (between 30 and $360 \mathrm{~min}$ ) was analysed by using a Varian 430 chromatograph equipped with CPSIL-5CB capillary column (length: $50 \mathrm{~m}$; diameter: $0.25 \mathrm{~mm}$, film thickness: $0.4 \mu \mathrm{m}$ ) and a flame ionization detector. The oven temperature was programmed from $70{ }^{\circ} \mathrm{C}$ to $150{ }^{\circ} \mathrm{C}\left(5^{\circ} \mathrm{C}\right.$ $\left.\mathrm{min}^{-1}\right)$, then from $150{ }^{\circ} \mathrm{C}$ to $250{ }^{\circ} \mathrm{C}\left(10{ }^{\circ} \mathrm{C} \mathrm{min}^{-1}\right)$ and maintained at $250{ }^{\circ} \mathrm{C}$ during 10 minutes. All detected products were identified by co-injection of commercial samples and/or by using Varian 3800 chromatograph coupled with a 1200 TQ mass spectrometer.

The conversion of furfural $\left(X_{F}\right.$ in \%) and the yield in each product $(Y$ in $\mathrm{mol} \%$ ) were calculated using the following equations, according to $\mathrm{O}^{\prime}$ Neill et al. : ${ }^{42}$

$$
\begin{aligned}
& X_{F}=\frac{C_{F, 0}-C_{\mathrm{F}}}{C_{F, 0}} \cdot 100 \\
& Y_{F A C O H}=\frac{C_{\mathrm{FAcOH}}}{C_{F, 0}} \cdot 100 \\
& Y_{F A c}=\frac{C_{\mathrm{FAc}}}{C_{F, 0}} \cdot 100 \\
& Y_{F_{2} A c}=\frac{2 \cdot C_{\mathrm{F} 2 \mathrm{Ac}}}{C_{F, 0}} \cdot 100
\end{aligned}
$$

with $\mathrm{C}_{\mathrm{F}, 0}$ being the initial concentration of furfural, $\mathrm{C}_{\mathrm{F}}, \mathrm{C}_{\mathrm{FACOH}}, \mathrm{C}_{\mathrm{FAC}}$ and $\mathrm{C}_{\mathrm{F} 2 \mathrm{AC}}$ being the concentrations of various compounds determined at a given reaction time. Whatever the catalysts, the molar balance carbon is between 95 and $100 \%$.

\section{Results and discussion}

\section{Characterization of the catalysts}

The so-called $\mathrm{Mg}(\mathrm{OH})_{2}$ sample was prepared by a sol gel method without added HF aqueous solution during the synthesis. The XRD pattern of this solid exhibited broad peaks highlighting a low rate of crystallinity (Fig. 1). 


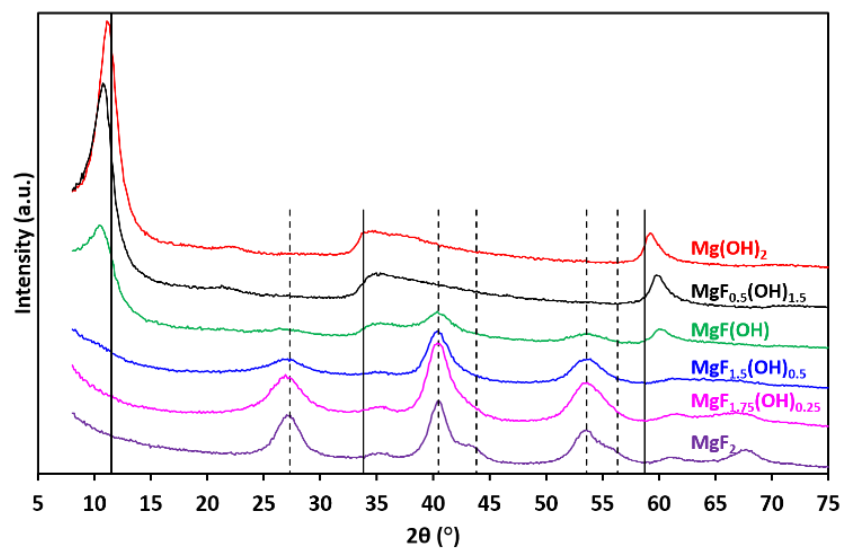

Fig. 1 X-ray diffraction patterns of $\mathrm{MgF}_{2-\mathrm{x}}(\mathrm{OH})_{\mathrm{x}}$ samples. Dotted lines: mean diffraction peaks of $\mathrm{MgF}_{2}$ (JCPDS file $\mathrm{N}^{\circ}$ 01-070-2268); solid lines: main diffraction peaks of $\mathrm{Mg}(\mathrm{OH})_{1.3}\left(\mathrm{OCH}_{3}\right)_{0.7}$ (JCPDS file $\mathrm{N}^{\circ} 00-022-1788$ )

As expected, the formation of layered-methoxide of magnesium with the $\mathrm{Mg}(\mathrm{OH})_{2-x}\left(\mathrm{OCH}_{3}\right)_{x}$ formula was observed attesting that the hydrolysis of magnesium alkoxide by water was incomplete even if water was added in excess, in agreement with Rywak et al. ${ }^{43} \mathrm{~A}$ weak shift towards lower angles of the peaks was observed in comparison with the peaks of the JCPDS file of the $\mathrm{Mg}(\mathrm{OH})_{1.3}\left(\mathrm{OCH}_{3}\right)_{0.7}$ material. This composition is probably not entirely the same as our synthetized material explaining this shift. This solid sample exhibited a microstructure composed of crumpled sheets as shown by transmission electron microscopy (Fig. 2). The observation of sheets is in accordance with the formation of layered-methoxide magnesium as observed by XRD (Fig. 1). As expected from the stoichiometry of this sample $\left(\mathrm{Mg}(\mathrm{OH})_{2-x}\left(\mathrm{OCH}_{3}\right)_{x}\right)$, the $\mathrm{O} / \mathrm{Mg}$ ratio determined by EDS was close to 2.0. Using the same technic, the carbon content of this material was also evaluated. Indeed, a value of $x$ corresponding to the number of $\mathrm{OCH}_{3}$ groups was approximately ranged between 0.5 and 0.9 , close to the reference indicated in XRD patterns (equal to 0.7 ). The presence of such methoxy groups was confirmed by FT-IR (Fig. 3). Indeed, the bands between 2800 and $2950 \mathrm{~cm}^{-1}$ can be assigned to $\mathrm{OCH}_{3}$ groups. $^{44}$
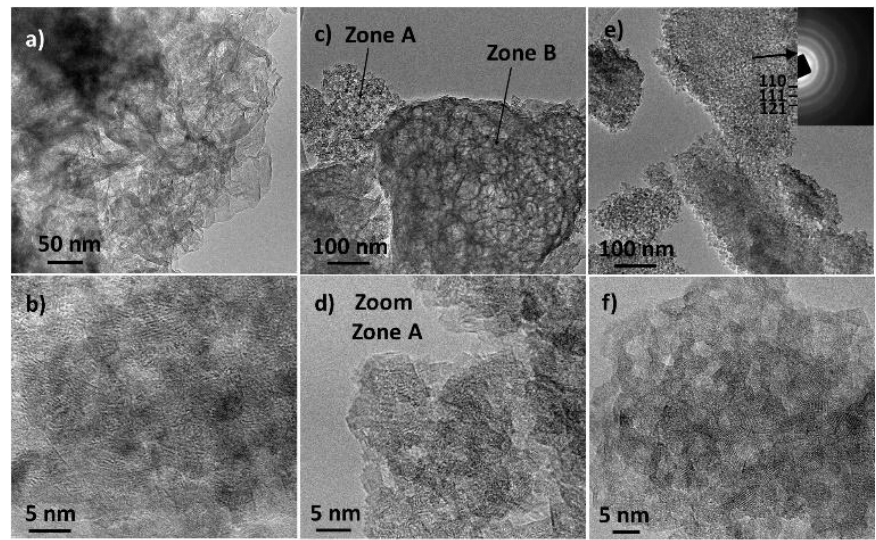

Fig. 2 TEM images of $M g(O H)_{2}$ (a and b), $M g F(O H)$ (c and d) and $M_{2} F_{2}$ (e and f). Corresponding SAED pattern (insert image) of picture $\mathrm{e}$

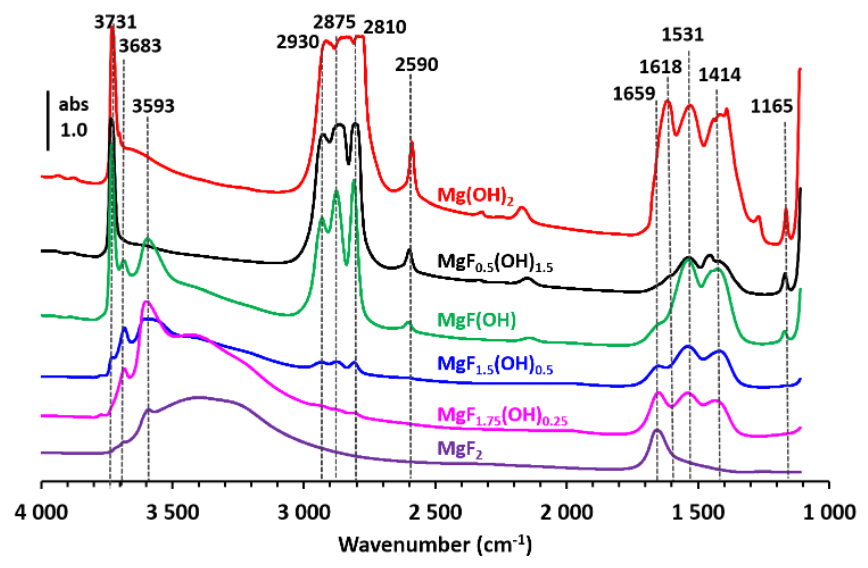

Fig. 3: IR spectra of $\mathrm{MgF}_{2-x}(\mathrm{OH})_{x}$ samples after activation at $90^{\circ} \mathrm{C}$ under vacuum

When an initial $\mathrm{HF} / \mathrm{Mg}$ ratio equal to 2 was used during the synthesis, the solid corresponds to $\mathrm{MgF}_{2}$ crystallographic phase as shown by XRD (Fig 1). The F/Mg molar ratio was determined by a combination of ICP-OES for Mg content, and ionic chromatography for $\mathrm{F}$ content. The value, given in Table 1 , is in agreement with the expected one. This solid sample can be defined by a homogeneous porous structure composed of small crystallites of 4-7 $\mathrm{nm}$ as observed by TEM (Fig. 2). The F/Mg ratio determined by EDS was close to 2.1 whatever the analysed region attesting the formation of $\mathrm{MgF}_{2}$. From the corresponding energy-filtered SAED pattern, $\mathrm{d}$ spacing of 3.4, 2.2 and $1.7 \AA$ A were determined and corresponded to (110), (111) and (121) diffraction planes of $\mathrm{MgF}_{2}$.

Several magnesium hydroxide fluorides solids $\mathrm{MgF}_{2-\mathrm{x}}(\mathrm{OH})_{\mathrm{x}}$, with $\mathrm{x}$ equal to $0.25,0.5,1,1.5$ and 1.75 , were also prepared by a sol-gel method as described in the experimental part. For each solid sample, the experimental $\mathrm{F} / \mathrm{Mg}$ ratio was close to the target value (Table 1). In these conditions, a competition between fluorolysis (reaction with $\mathrm{HF}$ ) and hydrolysis (reaction with $\mathrm{H}_{2} \mathrm{O}$ ) occurred. As the rate of the former reaction being higher, the fluorine content in the magnesium hydroxide fluoride is easily tuned and reasonably controlled by the initial $\mathrm{HF} / \mathrm{Mg}$ molar ratio thanks to this sol-gel method and increases linearly with the amount of HF added, in agreement with results reported by Prescott et al. ${ }^{35}$ In these samples, at least two crystallographic phases can be detected (Fig. 1). For example, the XRD pattern of $\mathrm{MgF}(\mathrm{OH})$ sample exhibited the peaks of both $\mathrm{MgF}_{2}$ and $\mathrm{Mg}(\mathrm{OH})_{2-\mathrm{x}}\left(\mathrm{OCH}_{3}\right)_{x}$ phases. As expected, higher the initial $\mathrm{HF} / \mathrm{Mg}$ molar ratio used in solid synthesis is, higher the contribution of the $\mathrm{MgF}_{2}$ phase in the considered pattern is at the expense of $\mathrm{Mg}(\mathrm{OH})_{2-x}\left(\mathrm{OCH}_{3}\right)_{x}$ phase. 
Table 1: Physico-chemical properties of magnesium hydroxide fluoride $\mathrm{MgF}_{2-x}(\mathrm{OH})_{x}$ samples

\begin{tabular}{cccccc}
\hline Catalyst & $\begin{array}{c}\mathrm{F} / \mathrm{Mg} \\
\text { ratio }^{1}\end{array}$ & $\begin{array}{c}\mathrm{S}_{\text {BET }}{ }^{2} \\
\left(\mathrm{~m}^{2} \mathrm{~g}^{-1}\right)\end{array}$ & $\begin{array}{c}\mathrm{V}_{\text {pore }}{ }^{3} \\
\left(\mathrm{~cm}^{3} \mathrm{~g}^{-1}\right)\end{array}$ & $\begin{array}{c}\mathrm{d}_{\text {pore }}{ }^{4} \\
(\mathrm{~nm})\end{array}$ & $\begin{array}{c}\text { Basicity }^{5} \\
\text { (a.u. })\end{array}$ \\
\hline $\mathrm{Mg}(\mathrm{OH})_{2}$ & 0 & 313 & 0.56 & 6.1 & 0.005 \\
$\mathrm{MgF}_{0.5}(\mathrm{OH})_{1.5}$ & 0.4 & 630 & 0.73 & 4.5 & 0.039 \\
$\mathrm{MgF}(\mathrm{OH})$ & 1.1 & 599 & 0.75 & 5.2 & 0.069 \\
$\mathrm{MgF}_{1.5}(\mathrm{OH})_{0.5}$ & 1.6 & 406 & 0.75 & 7.2 & 0.174 \\
$\mathrm{MgF}_{1.75}(\mathrm{OH})_{0.25}$ & 1.8 & 387 & 0.55 & 6.0 & 0.068 \\
$\mathrm{MgF}_{2}$ & 2.0 & 280 & 0.26 & 4.4 & 0
\end{tabular}

[1] Fluor content measured by ionic chromatography and $\mathrm{Mg}$ content measured by ICP-OES; [2] Specific surface area measured by the BET method; [3] Total pore volume calculated at $P / P_{0}$ equal to 0.99; [4] Average pore size deduced from the $\mathrm{BJH}$ method using the desorption branch; [5] Determined from the area of the band at $1225 \mathrm{~cm}^{-1}$ obtained after activation at $90{ }^{\circ} \mathrm{C}$ under vacuum and adsorption-desorption of $\mathrm{CO}_{2}$ at $50{ }^{\circ} \mathrm{C}$ (values deduced from spectra presented in Fig. 4)

The formation of this intimate mixture of phases was confirmed by TEM analysis (Fig. 2). As an example, two well separated zones were visible in the TEM image for the $\mathrm{MgF}(\mathrm{OH})$ sample (Fig. 2c). The zone " $A$ " presents a microstructure comparable to $\mathrm{MgF}_{2}$ phase given in Fig. 2f. The determined F/Mg ratio of 1.9 by EDS was close to the expected value (equal to 2). The corresponding SAED (not shown in Fig 2d) was equivalent to the one inserted in Fig. 2e. The zone "B" with crumpled sheets is similar to the $\mathrm{Mg}(\mathrm{OH})_{2-x}\left(\mathrm{OCH}_{3}\right)_{x}$ phase shown in Fig. $2 \mathrm{~b}$. In addition, a O/F/Mg ratio of 1.2/0.9/1 measured by EDS, indicates the presence of an intimate mixture of $\mathrm{MgF}_{2}$ and $\mathrm{Mg}(\mathrm{OH})_{2-x}\left(\mathrm{OCH}_{3}\right)_{x}$ in the zone " $\mathrm{B}$ ". Nevertheless, the insertion of a fraction of fluorine in $\mathrm{Mg}(\mathrm{OH})_{2-x}\left(\mathrm{OCH}_{3}\right)_{x}$ and of hydroxyl group in $\mathrm{MgF}_{2}$ cannot be obviously excluded to form $\mathrm{MgF}_{2-x-y}(\mathrm{OH})_{x}\left(\mathrm{OCH}_{3}\right)_{y}$ mixed phase as already proposed. ${ }^{35}$ Moreover, taking into account the low crystallinity of these samples showed by XRD (Fig. 1), each phase is composed of randomly-dispersed small domain leading to a very close proximity and a high amount of interfaces between them.

The adsorption-desorption isotherms of all solids are shown in Fig. S1. A type IV isotherm according to the IUPAC classification was observed for all samples whatever the fluorine content showing the formation of mesoporous solids with a pore volume between 0.3 and $0.7 \mathrm{~cm}^{3} \mathrm{~g}^{-1}$ (Table 1). The average pore size determined by the $\mathrm{BJH}$ method is between 4 and $7 \mathrm{~nm}$ for all materials. The specific surface areas of these solids are very high (from $280 \mathrm{~m}^{2} \mathrm{~g}^{-1}$ for $\mathrm{MgF}_{2}$ to $630 \mathrm{~m}^{2} \mathrm{~g}^{-1}$ for $\mathrm{MgF}_{0.5}(\mathrm{OH})_{1.5}$ ), in accordance with the low crystallinity observed by XRD (Fig. 1). These surface areas are relatively close to the values obtained for the magnesium hydroxide fluorides prepared in similar conditions by Scholz et al. ${ }^{41}$ Interestingly, the specific surface areas of the $\mathrm{MgF}_{2-\mathrm{x}}(\mathrm{OH})_{\mathrm{x}}$ samples were drastically higher than those of $\mathrm{MgF}_{2}$ and $\mathrm{Mg}(\mathrm{OH})_{2}$ pure materials. The synthesis of an intimate mixture of $\mathrm{MgF}_{2}$ and $\mathrm{Mg}(\mathrm{OH})_{2-x}\left(\mathrm{OCH}_{3}\right)_{x}$ allowed hence to obtain very high specific surface areas. This can be explained by a delay in the crystallization processes due to the presence of a second phase which affects the rate of crystallization of the first one. ${ }^{36}$ This phenomenon is in favour of the nanoparticles formation, as observed by TEM (Fig. 2).
After their activation under secondary vacuum at $90{ }^{\circ} \mathrm{C}$, all catalysts, initially synthesized at $100^{\circ} \mathrm{C}$, were characterized by FT-IR before (Fig. 3) and after $\mathrm{CO}_{2}$ adsorption (Fig. 4). Concerning the spectra shown in Fig. 3, the sharp band observed around $3730 \mathrm{~cm}^{-1}$ is assigned to $\mathrm{U}_{(\mathrm{MgO}-\mathrm{H})}{ }^{41}$ As expected, the intensity of this band decreases with the increase of the fluorine content, due to the lower amount of $\mathrm{OH}$ groups. According to Prescott et al., ${ }^{35}$ a weak band centred at $3683 \mathrm{~cm}^{-1}$ can be attributed to the bridging of $\mathrm{OH}$ groups in $\mathrm{MgF}_{2-x}(\mathrm{OH})_{x}$ samples, especially observed when $\mathrm{x} \leq 1$, i.e. for $\operatorname{MgF}(\mathrm{OH}), \mathrm{MgF}_{1.5}(\mathrm{OH})_{0.5}$ and $\mathrm{MgF}_{1.75}(\mathrm{OH})_{0.25}$ samples. The bands at 2930,2870 and $2810 \mathrm{~cm}^{-1}$ can be attributed to $U_{(\mathrm{CH})}$ of the methoxy groups present in these magnesium hydroxide fluoride samples. ${ }^{41}$ The decrease of their intensity with the increase of $\mathrm{F}$ content can be explained by the lower amount of $\mathrm{Mg}(\mathrm{OH})_{2-\mathrm{x}}\left(\mathrm{OCH}_{3}\right)_{\mathrm{x}}$ phase in the solid samples, in accordance with XRD analysis. The strong bands between 1650 and $1400 \mathrm{~cm}^{-1}$ originate from carbonate and hydrogen carbonate species formed by the reaction of atmospheric $\mathrm{CO}_{2}$ with the $\mathrm{MgF}_{2-\mathrm{x}}(\mathrm{OH})_{\mathrm{x}}$ materials basic sites. ${ }^{35,41}$ The strong intensity of these bands observed for the $\mathrm{Mg}(\mathrm{OH})_{2}$ solid can be explained by the highest basicity of such solid. In addition, adsorbed water can lead to a broad band located between 3400$3600 \mathrm{~cm}^{-1}$ and a sharp band around $1659 \mathrm{~cm}^{-1}$, as reported by Rywak et al. ${ }^{43}$ These bands were particularly intense on IR spectra of solids having $x \leq 0.5$, indicating that the presence of fluorine seems to favour the retention of adsorbed water. This is probably linked to the increase of the Lewis acidity of solid samples with the fluorine content as confirmed below with the characterization of acidity. It can be noted that the activation step used for IR analysis (degassing at $90^{\circ} \mathrm{C}$ under vacuum) was insufficient to remove all the water adsorbed on these samples.

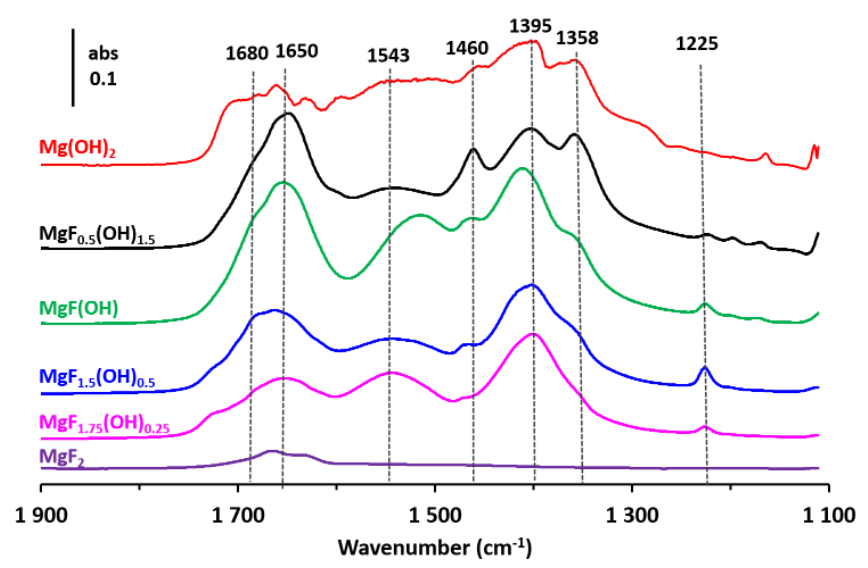

Fig. 4 Difference of IR spectra obtained after $\mathrm{CO}_{2}$ adsorption at $50{ }^{\circ} \mathrm{C}$ and after activation at $90{ }^{\circ} \mathrm{C}$ under vacuum of $\mathrm{MgF}_{2-\mathrm{x}}(\mathrm{OH})_{\mathrm{x}}$ samples with $0 \leq \mathrm{x} \leq 2$

According to the results reported by Wuttke et al., ${ }^{45}$ the $\mathrm{OH}$ groups present on such $\mathrm{MgF}_{2-\mathrm{x}}(\mathrm{OH})_{x}$ materials exhibit either acidic or basic properties. This is obviously due to the stronger inductive effect of fluorine atoms in comparison to oxygen atoms. Thus, the easy control of the $\mathrm{F} / \mathrm{Mg}$ ratio of these materials by sol-gel process allows to fine tune their acid-base properties. When $\mathrm{x}$ is low (about less than 0.1 ) corresponding to the so-called $\mathrm{MgF}_{2}$ in the present 
study, it was proposed that $\mathrm{OH}$ groups in minor quantities are Brønsted acid sites and this solid is an acidic material, exhibiting mainly Lewis acidity attributed to the presence of under coordinated $\mathrm{Mg}^{2+}$ species. ${ }^{46,47}$ It can explain the absence of IR bands in the carbonate and hydrogen carbonate region (between 1350 and $1640 \mathrm{~cm}^{-1}$ ) as shown in Fig. 3. On the contrary, with $x$ higher than 0.1 , the $\mathrm{OH}$ groups can be considered as basic sites. Consequently, several bands between 1350 and $1640 \mathrm{~cm}^{-1}$ can be observed due to reaction between hydroxyl groups and atmospheric $\mathrm{CO}_{2}$. Besides, their intensity increased with the decrease of the fluorine content.

To deeper understand the acid-base properties of the assynthesized $\mathrm{MgF}_{2-x}(\mathrm{OH})_{x}$ samples, additional experiments using $\mathrm{CO}_{2}$ adsorption-desorption procedure were carried out at $50{ }^{\circ} \mathrm{C}$ under vacuum. The spectra presented in Fig. 4 were obtained through subtraction between the spectrum realized after $\mathrm{CO}_{2}$ adsorption followed by heating at $50{ }^{\circ} \mathrm{C}$ under vacuum and those measured after the activation procedure at $90{ }^{\circ} \mathrm{C}$ (presented in Fig. 3). As expected, no bands were observed for $\mathrm{MgF}_{2}$ highlighting the absence of basic sites on this solid. For all other samples, several bands appeared between $1100-1900 \mathrm{~cm}^{-1}$, showing that some basic sites remained available to adsorb $\mathrm{CO}_{2}$ and to form carbonate and bicarbonate species. ${ }^{48-50}$ The decrease of the fluorine content is linked to an increase of several bands, including notably those located at 1358 and $1460 \mathrm{~cm}^{-1}$, which could be attributed to the presence of carbonate species. These species can be formed on strong basic sites. On the contrary, the band at $1225 \mathrm{~cm}^{-1}$ which corresponds to the $\delta_{(\mathrm{OH})}$ vibration of hydrogen carbonate species, allows to evaluate the presence of basic sites with moderate strength. The area of this band was reported in Table 1 for all solids. Surprisingly, the amount of these sites increases with the fluorine content in $\mathrm{MgF}_{2-\mathrm{x}}(\mathrm{OH})_{\mathrm{x}}$ series ( $\mathrm{x}$ in the range of $2-0.5$ ), whereas the inductive effect of fluorine is rather known to decrease the basicity of the solids. ${ }^{45}$ The higher amount of basic hydroxyl group with low strength can be explained by the higher amount of fluorine in the vicinity of this hydroxyl group leading to decrease the strength of basicity. In the case of low-fluorine-containing magnesium hydroxide fluorides, the majority of hydroxyl groups are probably basic with high strength which react with $\mathrm{CO}_{2}$ of ambient air. Thus, the fluorine atoms included in these materials act as stabilizer of basic hydroxyl groups with low strength explaining why $\mathrm{MgF}_{1.5}(\mathrm{OH})_{0.5}$ retains higher amount of basic hydroxyl groups.

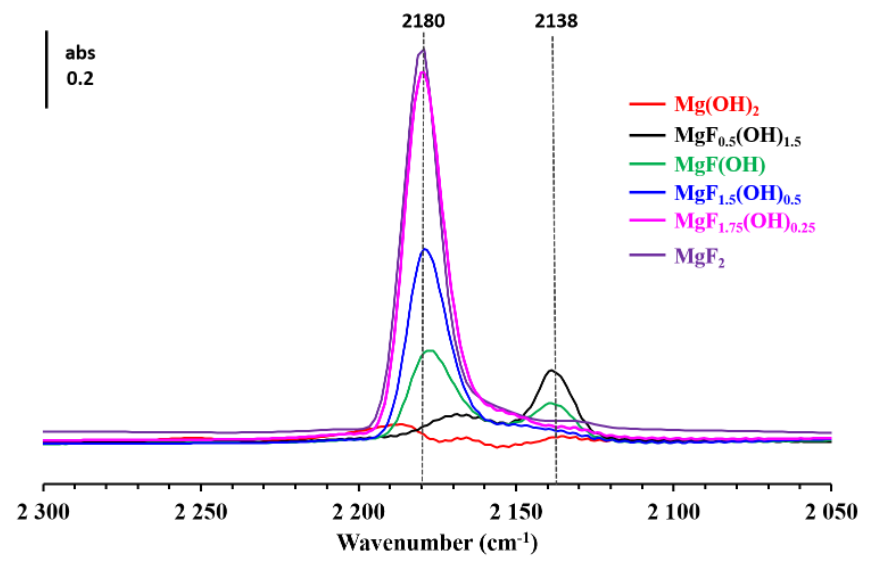

Fig. 5 Difference of IR spectra obtained after $\mathrm{CO}$ adsorption at saturation at $-173^{\circ} \mathrm{C}$ and after activation at $90^{\circ} \mathrm{C}$ under vacuum of $\mathrm{MgF}_{2-\mathrm{x}}(\mathrm{OH})_{\mathrm{x}}$ samples with $0 \leq \mathrm{x} \leq 2$.

The acid properties were also determined by adsorption of $\mathrm{CO}$ followed by IR. CO is a suitable probe molecule for the characterization of Lewis acidity because the $v(\mathrm{CO})$ frequency is very sensitive to the local cationic environment. ${ }^{51}$ After CO adsorption, this band shifts more or less depending on the strength of Lewis acidity: the stronger the Lewis acidity, the higher the shift. The spectra obtained after $\mathrm{CO}$ saturation for each catalyst are reported in Fig. 5. Except for $\mathrm{Mg}(\mathrm{OH})_{2}$ and $\mathrm{MgF}_{0.5}(\mathrm{OH})_{1.5}$, the main $v(\mathrm{CO})$ band is observed at $2180 \mathrm{~cm}^{-1}$ and corresponds to $\mathrm{CO}$ adsorbed on Lewis acid sites with moderate strength. ${ }^{52,53}$ Taking into account that no significant shift was observed in the $\mathrm{OH}$ region (around $3700 \mathrm{~cm}^{-1}$ ), which is characteristic of $\mathrm{CO}$ adsorption on Brønsted acid sites (not showed here), ${ }^{54}$ we can reasonably assigned the band at $2180 \mathrm{~cm}^{-1}$ to an interaction of $\mathrm{CO}$ with Lewis acid sites. The low amount of Brønsted acidity on $\mathrm{MgF}_{2}$ prepared in the same conditions was already observed. ${ }^{47}$ Conversely, $\mathrm{Mg}(\mathrm{OH})_{2}$ and $\mathrm{MgF}_{0.5}(\mathrm{OH})_{1.5}$ have not or few Lewis acid sites. Only a band at $2138 \mathrm{~cm}^{-1}$ is observed corresponding to the weak and unspecific $\mathrm{CO}$ adsorption (physisorbed $\mathrm{CO}$ species). ${ }^{53}$ As expected, the amount of Lewis acidity increases with the fluorine content as showed by the increase of the surface of the IR band located at $2180 \mathrm{~cm}^{-1}$.

\section{Catalytic properties of magnesium hydroxide fluorides}

The activity of magnesium hydroxide fluorides were evaluated in aldol condensation of furfural (Furf) and acetone (AC) at $50{ }^{\circ} \mathrm{C}$ under atmospheric pressure. Except for the $\mathrm{MgF}_{2}$ sample which was totally inactive in this reaction, furfural conversion increased with the increase of the experiment duration (Fig. 6). The $\mathrm{Mg}(\mathrm{OH})_{2}$ sample, which was synthesized in absence of fluorine, led to only a conversion of furfural close to $13 \%$ after $6 \mathrm{~h}$ of reaction. Interestingly, the presence of fluorine in solids favoured their catalytic properties for aldol condensation of furfural. Indeed, the conversions of furfural ranged between 19 and $84 \%$ after 6 hours, depending on the $\mathrm{F} / \mathrm{Mg}$ ratio used, the most active being the $\mathrm{MgF}_{1.5}(\mathrm{OH})_{0.5}$ sample. It can be mentioned that the difference in the specific surface area between catalysts seems not to be a key parameter to explain the difference in the catalytic properties of 
the magnesium hydroxide fluorides. Indeed, $\operatorname{MgF}_{1.5}(\mathrm{OH})_{0.5}$ exhibited a lower specific surface area than $\mathrm{MgF}_{0.5}(\mathrm{OH})_{1.5}, 406$ and $630 \mathrm{~m}^{2} \mathrm{~g}^{-1}$, respectively (Table 1 ), but the former was about 2.7 times more active than the latter (Fig. 7). In the same way, while the specific surface areas of $\mathrm{MgF}_{1.5}(\mathrm{OH})_{0.5}$ and $\mathrm{MgF}_{1.75}(\mathrm{OH})_{0.5}$ are very close (406 and $387 \mathrm{~m}^{2} \mathrm{~g}^{-1}$, respectively), the former is much more active than the latter (Fig. 7). Such a finding was already observed for several mixed-oxides using as catalysts for aldol condensation of furfural and acetone ${ }^{24}$. On the other hand, commercial MgO basic catalyst was also evaluated for this reaction under the same experimental conditions (without activation step). The obtained conversion was only $13 \%$ after $6 \mathrm{~h}$ of reaction showing the interest of using hydroxide fluoride as catalyst for the aldol condensation of furfural by acetone.

The initial reaction rate of each catalyst can be evaluated by taking the tangent at the origin of each curve depicted in Fig. 6 . Interestingly, a linear correlation was found between the initial reaction rate and the $\mathrm{F} / \mathrm{Mg}$ molar ratio until 1.5 (Fig. 7). Indeed, an increase of the $\mathrm{F} / \mathrm{Mg}$ ratio in the catalyst, between 0 and 1.5 , favored the reaction rate in aldol condensation. Nevertheless, the two samples with the highest $\mathrm{F} / \mathrm{Mg}$ ratios (1.75 and 2) exhibited a very limited activity. The initial reaction rate of $\mathrm{MgF}_{1.75}(\mathrm{OH})_{0.25}$ was about 7 times lower than the one of $\mathrm{MgF}_{1.5}(\mathrm{OH})_{0.5}$, and $\mathrm{MgF}_{2}$ was totally inactive. It was already reported that this type of catalyst exhibited virtually only acidity. ${ }^{40,47}$ This is here confirmed by the characterization of acid-base properties using both $\mathrm{CO}$ and $\mathrm{CO}_{2}$ probe molecules. As proposed by Kikhtyanin et al., ${ }^{26}$ such reaction was rather catalyzed by Brønsted acid sites explaining, at least in part, the poor catalytic properties of $\mathrm{MgF}_{2}$ for aldol condensation of furfural. Moreover, acidic catalysts were often used in more drastic experimental conditions, between $100{ }^{\circ} \mathrm{C}^{29,30}$ and $140{ }^{\circ} \mathrm{C}^{28}$, i.e. at higher temperature than the one used in the present study $\left(50^{\circ} \mathrm{C}\right)$.

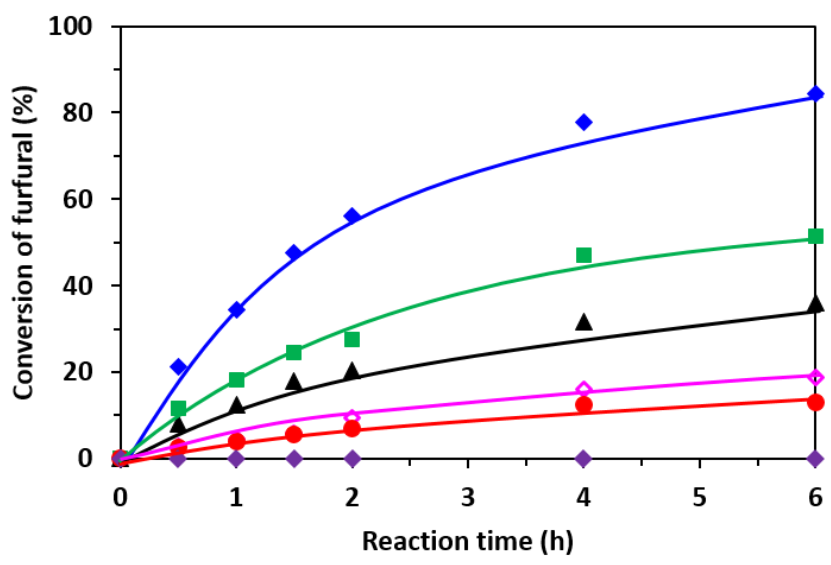

Fig. 6 Aldol condensation of furfural and acetone over magnesium hydroxide fluorides $\left(\mathrm{MgF}_{2-\mathrm{x}}(\mathrm{OH})_{\mathrm{x}}\right)$ at $50^{\circ} \mathrm{C}$ under atmospheric pressure (furfural/acetone ratio equal to 0.5 ). Influence of the reaction time on the conversion of furfural. over $\mathrm{Mg}(\mathrm{OH})_{2}(0)$, $\mathrm{MgF}_{0.5}(\mathrm{OH})_{1.5}(\boldsymbol{\Delta}), \operatorname{MgF}(\mathrm{OH})(\square), \mathrm{MgF}_{1.5}(\mathrm{OH})_{0.5}(\diamond), \mathrm{MgF}_{1.75}(\mathrm{OH})_{0.25}(\diamond)$ and $\mathrm{MgF}_{2}(\diamond)$

A correlation was also found between the $\mathrm{F} / \mathrm{Mg}$ molar ratio and the surface of the IR band at $1225 \mathrm{~cm}^{-1}$ measured after adsorption of
$\mathrm{CO}_{2}$ as shown in Fig. 7. As indicated in the previous part, such band corresponds to $\delta_{(\mathrm{OH})}$ of hydrogen carbonate species and allows to quantify the number of basic sites with moderate strength. ${ }^{48-50}$ Consequently, the aldol condensation activity can be directly connected to the number of $\mathrm{OH}$ groups involved in the formation of hydrogen carbonate species deduced from $\mathrm{CO}_{2}$ adsorption experiments. Such correlation was already reported between the activity for carbon oxysulfide hydrolysis of various mixed oxides $\left(\mathrm{TiO}_{2}-\mathrm{Al}_{2} \mathrm{O}_{3}, \mathrm{TiO}_{2}-\mathrm{ZrO}_{2}\right.$ and $\mathrm{ZrO}_{2}-\mathrm{Al}_{2} \mathrm{O}_{3}$ ) and the intensity of the band at $1225 \mathrm{~cm}^{-1} .{ }^{48,49}$ As observed in Fig. 4, other basic sites are present in our samples characterized by the bands at 1358 and $1460 \mathrm{~cm}^{-1}$ attributed to the presence of carbonates species produced by reaction with $\mathrm{CO}_{2}$. The intensity of these bands increases with the decrease of fluorine in the magnesium hydroxide fluoride (Fig 4), which is the opposite of the catalytic properties evolution (Fig. 7). Nevertheless, we cannot totally exclude their involvement in the aldol condensation reaction as active sites, even if their influence is probably minor.

For this reaction, the involvement of two types of active sites has been suggested: electron-donating sites (hydroxyl ions and/or oxide-ion defect) acting as reduced sites and Lewis acidic sites (coordinatively unsaturated metal site). ${ }^{55}$ Similarly, we can propose the participation of two types of sites to explain the catalytic properties of the $\mathrm{MgF}_{2-\mathrm{x}}(\mathrm{OH})_{\mathrm{x}}$ solid materials: a vacancy on magnesium present on the $\mathrm{MgF}_{2}$ phase, acting as Lewis acid site, and hydroxyl groups with moderate strength present on $\mathrm{Mg}(\mathrm{OH})_{2}$ phase, acting as basic site (Scheme 2). The reaction was then produced at the interface between both phases where basic and acid sites are close and it was facilitated by the probable high concentration of interfaces in these nanoscopic materials as discussed previously. Moreover, since the formation of amorphous $\mathrm{MgF}_{2-x-y}(\mathrm{OH})_{x}\left(\mathrm{OCH}_{3}\right)_{y}$ mixed phase cannot be excluded, some acidpair sites can be also present on the same phase: a Lewis acid site (undercoordinated magnesium stabilized by the presence of fluorine) in the vicinity of a basic site (hydroxyl group). In order to validate this hypothesis, a mechanical mixture containing $25 \mathrm{wt} \%$ of $\mathrm{Mg}(\mathrm{OH})_{2}$ and $75 \mathrm{wt} \%$ of $\mathrm{MgF}_{2}$ was evaluated as catalyst for this reaction. The initial rate of this mechanical mixture was about 17 times lower than the one of the corresponding $\operatorname{MgF}_{1.5}(\mathrm{OH})_{0.5}$ confirming the necessity to have neighboring sites obtained thanks to the intimate mixture of $\mathrm{MgF}_{2}$ and $\mathrm{Mg}(\mathrm{OH})_{2-\mathrm{x}}\left(\mathrm{OCH}_{3}\right)_{x}$ prepared by the sol-gel method used in our work. 


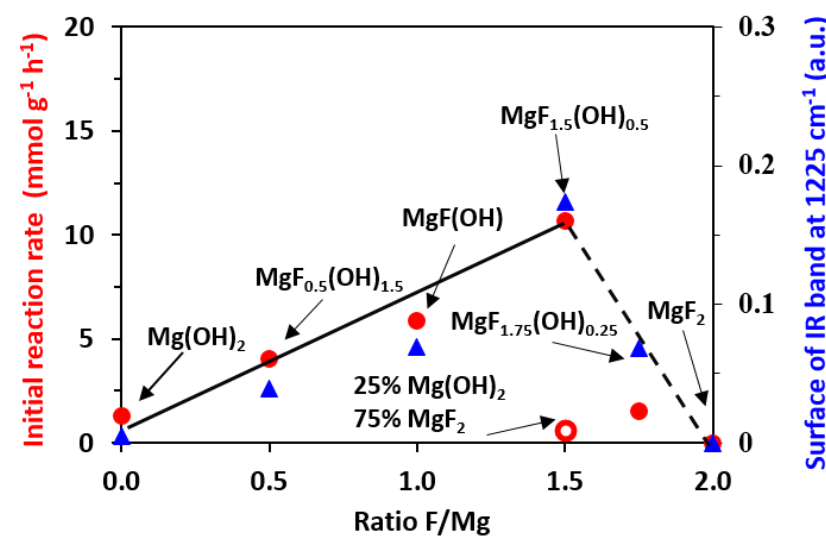

Fig. 7 Aldol condensation of furfural and acetone over magnesium hydroxide fluorides $\mathrm{MgF}_{2-\mathrm{x}}(\mathrm{OH})_{\mathrm{x}}$ and over a mechanical mixture composed by $25 \mathrm{wt} \%$ of $\mathrm{Mg}(\mathrm{OH})_{2}$ and 75 wt $\%$ of $\mathrm{MgF}_{2}$ at $50{ }^{\circ} \mathrm{C}$ under atmospheric pressure (furfural/acetone ratio equal to 0.5 ). Effect of the F/Mg molar ratio (i) on the initial reaction rate of aldol condensation of furfural by acetone (red) and (ii) on the number of medium basic sites evaluated by the area of the band determined at $1225 \mathrm{~cm}^{-1}$ after $\mathrm{CO}_{2}$ adsorption-desorption at $50{ }^{\circ} \mathrm{C}$ (blue).

The basic site can lead to the formation of carbanion species from the abstraction of the $\alpha$-proton from acetone (Scheme 2 ). The Lewis acid site could favor the nucleophile addition onto furfural through its adsorption by the oxygen atom of the carbonyl group. Such assumption, i.e. the participation of a Lewis acid site located in the vicinity of a basic site with medium strength, to explain the catalytic properties of different mixed-oxide catalysts (Mg-Zr, Mg-Al and $\mathrm{Ca}-\mathrm{Zr}$ ) in aldol condensation of furfural, has been already suggested by Faba et al. ${ }^{24}$ In addition, these authors proposed that the activity of mixed-oxide catalysts was promoted by mediumstrength base sites, in accordance with our proposals.

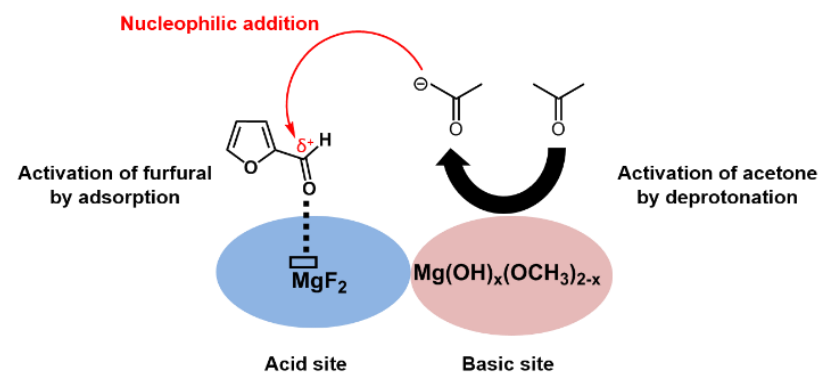

Scheme 2: Proposals concerning the active sites involved during the aldol condensation of furfural and acetone

It is very important to mention that all $\mathrm{MgF}_{2-\mathrm{x}}(\mathrm{OH})_{\mathrm{x}}$ samples were used without any treatment. Indeed, as basic solids are very sensitive to ambient atmosphere by reaction with several molecules such as $\mathrm{H}_{2} \mathrm{O}$ or $\mathrm{CO}_{2}$, it is known that their use as basic catalysts requires a pre-treatment at a high temperature $\left(300-800{ }^{\circ} \mathrm{C}\right.$ depending on the solid composition and the basic site strength) before reaction in order to reveal basic sites on the catalytic surface. ${ }^{56}$ For example, the calcination of a Mg-Al hydrotalcite material at $450{ }^{\circ} \mathrm{C}$ resulted in a doubling of the furfural conversion for its aldol condensation. ${ }^{25}$ In addition, this activation step can lead to a drastic decrease of the specific surface area of the solid and thus of the amount of active sites. The preparation of basic solid catalysts allowing to retain basic sites without a calcination step is hence very attractive for, at least, both reasons: (i) to avoid costly heat-treatment for an industrial process, particularly for a reaction performed at low temperature (lower than $100{ }^{\circ} \mathrm{C}$ ) which not requires devices adapted for high temperature, (ii) to retain high specific surface area which will be favourable to maintain high active site concentration.

Table 2: Aldol condensation of furfural and acetone at $50{ }^{\circ} \mathrm{C}$ under atmospheric pressure over magnesium hydroxide fluorides. Effect of the catalyst on the product distribution determined at the same level of conversion of furfural (close to 30\%) except for $\mathrm{Mg}(\mathrm{OH})_{2}$

\begin{tabular}{|c|c|c|c|c|}
\hline \multirow[b]{2}{*}{ Catalyst } & \multirow{2}{*}{$\begin{array}{c}\text { Conv. } \\
\text { Furfural } \\
(\%)\end{array}$} & \multicolumn{3}{|c|}{ Distribution of products (\%) } \\
\hline & & $\mathrm{FAC}-\mathrm{OH}$ & FAc & $\mathrm{F}_{2} \mathrm{Ac}$ \\
\hline $\mathrm{Mg}(\mathrm{OH})_{2}$ & 13 & 30 & 35 & 35 \\
\hline $\mathrm{MgF}_{0.5}(\mathrm{OH})_{1.5}$ & 34 & 16 & 34 & 50 \\
\hline $\operatorname{MgF}(\mathrm{OH})$ & 28 & 19 & 37 & 44 \\
\hline $\mathrm{MgF}_{1.5}(\mathrm{OH})_{0.5}$ & 34 & 16 & 36 & 48 \\
\hline $\mathrm{MgF}_{1.75}(\mathrm{OH})_{0.25}$ & 27 & 17 & 33 & 50 \\
\hline
\end{tabular}

The ability to reuse the $\operatorname{MgF}_{1.5}(\mathrm{OH})_{0.5}$ sample catalyst was also investigated. For that, after $6 \mathrm{~h}$ of aldol condensation, the spent catalyst was filtered and dried at $90{ }^{\circ} \mathrm{C}$ during a night. The recovered catalyst was introduced in a new reaction mixture (second run). Unfortunately, the furfural conversion obtained after 6 hours during this second run was only close to $10 \%$. This value was thus much lower than the one obtained during the first run (equal to $84 \%$, Fig. 6) showing a strong deactivation of this kind of catalyst. As an evidence, further investigations are needed to understand the deactivation mode that occurs and to investigate experimental procedures allowing to restore their catalytic properties. Obviously, this procedure should not include heat treatment at high temperatures in order to keep the advantages of using these catalysts without activation step. This is, however, outside the topic of the present study and hence we will discuss this research topic in a forthcoming publication.

The effect of the reaction time on the conversion of furfural and on the yields of all detected products over $\mathrm{MgF}_{1.5}(\mathrm{OH})_{0.5}$ is given in Fig. S2 (see ESI). As expected, three products were observed, their quantity depending on the reaction time. Accordingly with the accepted reaction route, aldol condensation of furfural and acetone over magnesium hydroxide fluorides results in the successive formation of FAc-OH (4-(furan-2-yl)-4-hydroxybutan-2-one), FAc (4(furan-2-yl)but-3-en-2-one) and $F_{2} A c$ (1,5-di(furan-2-yl)penta-1,4dien-3-one), as depicted in Scheme 1. Surprisingly, FAc-OH, expected as the only primary product, was detected in low quantities even at low level of furfural conversion, its yield being only equal to $4 \mathrm{~mol} \%$ at $22 \mathrm{~mol} \%$ of conversion (after $30 \mathrm{~min}$ of reaction). An increase of the reaction time led to an increase of the yield of the two other products: FAc obtained by dehydration of 
$\mathrm{FAc}-\mathrm{OH}$, and $\mathrm{F}_{2} \mathrm{Ac}$ arising from interaction of $\mathrm{FAc}-\mathrm{OH}$ with another furfural molecule. Irrespective the reaction time and thus the furfural conversion, the furanic dimer $\left(F_{2} A c\right)$ was always the main product. This result can be explained by the fact that the kinetic constant of the final reaction (condensation of FAc and Furf) is much greater than the condensation of acetone and furfural yielding C8 units (initial reactions), as demonstrated by Faba et al. ${ }^{24}$ In addition, as shown in Table 2, the selectivity of the four catalysts containing fluoride was practically independent on their fluorine content. Indeed, the main product was always the furanic dimer, its amount being close to 50 mol\% irrespective of the catalyst. As $F_{2} A c$ is a more bulky molecule compared to FAc, the fact that the former was favoured compared to the latter over magnesium hydroxide fluoride catalysts seems to indicate the absence of diffusion limitations over these mesoporous catalysts. It is important to emphasize that diacetone alcohol produced by aldol condensation of acetone was never detected in our experimental conditions.

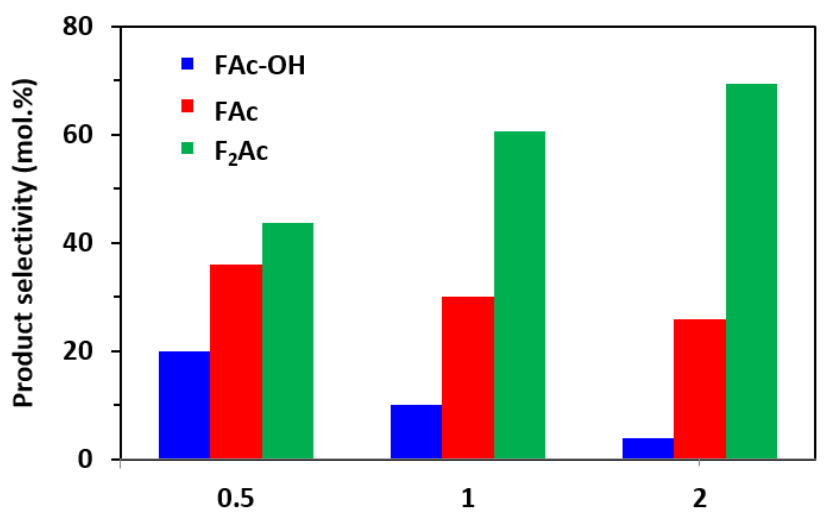

Furfural /acetone ratio

Fig. 8 Aldol condensation of furfural and acetone over $\operatorname{MgF}_{1.5}(\mathrm{OH})_{0.5}$ at $50{ }^{\circ} \mathrm{C}$ under atmospheric pressure. Influence of the furfural/acetone ratio on the distribution of products at iso-conversion of furfural (close to $20 \%$ )

The influence of the composition of reactants feed on the catalytic properties of $\mathrm{MgF}_{1.5} \mathrm{OH}_{0.5}$ was also investigated. It can be observed that the molar ratio of reactants for aldol condensation plays a significant role in both the activity and the selectivity of the catalyst. Indeed, Fig. S3 (see ESI) shows that the presence of an excess of acetone favours the consumption of furfural by aldol condensation. Actually, with the same initial molar quantity of furfural $(5 \mathrm{mmol})$, the use of a furfural/acetone ratio equal to 0.5 allowed to convert more than $4 \mathrm{mmol}$ of furfural after 6 hours while the use of a furfural/acetone molar ratio equal to 2 led only to the transformation of $1.3 \mathrm{mmol}$ of furfural. As an evidence, the conversion of furfural is limited to $50 \%$ in the latter case. Consequently a higher furfural/acetone ratio diminishes considerably the initial reaction rate (from 10.7 to $2.5 \mathrm{mmol} \mathrm{g}^{-1} \mathrm{~h}^{-1}$ ) since an excess of furfural may engender unnecessary adsorption on Lewis acid sites and thereby could inhibit the access of acetone to the neighbour basic sites. As a result, less active carbanions species can be formed when an excess of furfural was used and hence restraining its transformation. However, an excess of furfural led to a better selectivity on furanic dimer $\left(\mathrm{F}_{2} \mathrm{Ac}\right)$ as highlighted in Fig. 8. Indeed, when the molar ratio of furfural/acetone was increased from 0.5 to 2 , the selectivity for the formation of dimer species $\left(F_{2} A c\right)$ increased by $38 \%$.

\section{Conclusions}

It was demonstrated that magnesium hydroxide fluorides $\mathrm{MgF}_{2}$ ${ }_{x}(\mathrm{OH})_{x}$ can be used as efficient catalysts without preliminary thermal activation for aldol condensation of furfural and acetone under mild conditions $\left(50{ }^{\circ} \mathrm{C}\right.$, under atmospheric pressure). A strong effect of the $\mathrm{F} / \mathrm{Mg}$ molar ratio used during the synthesis of fluorides on their catalytic properties was highlighted. An optimum was determined for a $\mathrm{F} / \mathrm{Mg}$ ratio equal to 1.5 . This optimum was attributed to the presence of an intimate mixture of $\mathrm{MgF}_{2}$ and $\mathrm{Mg}(\mathrm{OH})_{2}$ phases allowing to create active sites combined an under-coordinated magnesium in the $\mathrm{MgF}_{2}$ phase, acting as Lewis acid site, in the vicinity of hydroxyl groups with moderate strength in $\mathrm{Mg}(\mathrm{OH})_{2}$ ${ }_{x}\left(\mathrm{OCH}_{3}\right)_{x}$ phase. Moreover, it was highlighted that the presence of fluorine allows to stabilize the basic sites with moderate strength at ambient temperature, allowing to use these catalysts without pretreatment of activation, a great benefit for an industrial point of view. Such hydroxide fluoride catalyst favored the C13 dimer species, particularly in excess of furfural. The present work confirms the potential of nanosized magnesium hydroxide fluorides as heterogeneous acid-base catalysts for aldol condensation reactions. The easy tuning of their acid-base properties and their high specific surface area make them attractive for other reactions involved in catalytic processes.

\section{Conflicts of interest}

There are no conflicts to declare.

\section{Acknowledgements}

Minrui Xu acknowledges a PhD fellowship from Solvay. Stéphane Célerier, Frédéric Richard and Jean-Marc Clacens acknowledge financial support from the European Union (ERDF) and "Region Nouvelle Aquitaine".

\section{Notes and references}

1 A. Corma, S. Iborra and A. Velty, Chem. Rev., 2007, 107, 2411-2502.

2 G. W. Huber, S. Iborra and A. Corma, Chem. Rev., 2006, 106, 4044-4098.

3 H. Kobayashi and A. Fukuoka, Green Chem., 2013, 15, 17401763.

4 S. Dutta, S. De, B. Saha and M. I. Alam, Catal. Sci. Technol., 2012, 2, 2025-2036.

5 M. J. Climent, A. Corma and S. Iborra, Green Chem., 2014, 16, 516-547.

6 I. Delidovich, K. Leonhard and R. Palkovits, Energy Environ. Sci., 2014, 7, 2803-2830.

7 W. Xu, H. Wang, X. Liu, J. Ren, Y. Wang and G. Lu, Chem. Commun., 2011, 47, 3924-3926. 
8 L. Bui, H. Luo, W. R. Gunther and Y. Román-Leshkov, Angew. Chem. Int. Ed., 2013, 52, 8022-8025.

9 J. Wu, G. Gao, J. Li, P. Sun, X. Long and F. Li, Applied Catalysis B: Environmental, 2017, 203, 227-236.

10 Z. J. Brentzel, K. J. Barnett, K. Huang, C. T. Maravelias, J. A. Dumesic and G. W. Huber, ChemSusChem, 2017, 10, 13511355.

$11 \mathrm{H}$. Li, A. Riisager, S. Saravanamurugan, A. Pandey, R. S. Sangwan, S. Yang and R. Luque, ACS Catal., 2018, 8, 148187.

12 R. M. West, Z. Y. Liu, M. Peter and J. A. Dumesic, ChemSusChem, 2008, 1, 417-424.

13 R. Xing, A. V. Subrahmanyam, H. Olcay, W. Qi, G. P. van Walsum, H. Pendse and G. W. Huber, Green Chem., 2010, 12, 1933-1946.

14 J. Yang, N. Li, S. Li, W. Wang, L. Li, A. Wang, X. Wang, Y. Cong and T. Zhang, Green Chem., 2014, 16, 4879-4884.

15 Q. Xia, Y. Xia, J. Xi, X. Liu and Y. Wang, Green Chem., 2015, 17, 4411-4417.

16 R. Ramos, Z. Tišler, O. Kikhtyanin and D. Kubička, Catal. Sci. Technol., 2016, 6, 1829-1841.

17 L. Faba, E. Díaz and S. Ordóñez, Applied Catalysis B: Environmental, 2014, 160-161, 436-444.

18 L. Faba, E. Díaz and S. Ordóñez, Catal. Sci. Technol., 2015, 5, 1473-1484.

19 L. Faba, E. Díaz, A. Vega and S. Ordóñez, Catalysis Today, 2016, 269, 132-139.

20 R. Ramos, Z. Tišler, O. Kikhtyanin and D. Kubička, Applied Catalysis A: General, 2017, 530, 174-183.

21 N. Fakhfakh, P. Cognet, M. Cabassud, Y. Lucchese and M. D. de Los Ríos, Chemical Engineering and Processing: Process Intensification, 2008, 47, 349-362.

22 W. Shen, G. A. Tompsett, K. D. Hammond, R. Xing, F. Dogan, C. P. Grey, W. C. Conner, S. M. Auerbach and G. W. Huber, Applied Catalysis A: General, 2011, 392, 57-68.

23 I. Sádaba, M. Ojeda, R. Mariscal, J. L. G. Fierro and M. L. Granados, Applied Catalysis B: Environmental, 2011, 101, 638-648.

24 L. Faba, E. Díaz and S. Ordóñez, Applied Catalysis B: Environmental, 2012, 113, 201-211.

25 D. Nguyen Thanh, O. Kikhtyanin, R. Ramos, M. Kothari, P. Ulbrich, T. Munshi and D. Kubička, Catalysis Today, 2016, 277, 97-107.

26 O. Kikhtyanin, V. Kelbichová, D. Vitvarová, M. Kubů and D. Kubička, Catalysis Today, 2014, 227, 154-162.

27 M. Su, W. Li, T. Zhang, H. Xin, S. Li, W. Fan and L. Ma, Catal. Sci. Technol., 2017, 7, 3555-3561.

28 H. Li, Z. Xu, P. Yan and Z. C. Zhang, Green Chem., 2017, 19 , 1751-1756.

29 O. Kikhtyanin, D. Kubička and J. Čejka, Catalysis Today, 2015, 243, 158-162.

30 S. Rojas-Buzo, P. García-García and A. Corma, Green Chem., 2018, 20, 3081-3091.

31 S. Célérier and F. Richard, Catalysis Communications, 2015, 67, 26-30.

32 E. Kemnitz, Catal. Sci. Technol., 2015, 5, 786-806.

33 F. Frouri, S. Célérier, P. Ayrault and F. Richard, Applied Catalysis B: Environmental, 2015, 168, 515-523.

34 S. M. Coman, S. Wuttke, A. Vimont, M. Daturi and E. Kemnitz, Advanced Synthesis \& Catalysis, 2008, 350, 25172524.

35 H. A. Prescott, Z.-J. Li, E. Kemnitz, J. Deutsch and H. Lieske, J. Mater. Chem., 2005, 15, 4616-4628.

36 M. Wojciechowska, A. Wajnert, I. Tomska-Foralewska, M. Zieliński and B. Czajka, Catal Lett, 2009, 128, 77-82.

37 I. Tomska-Foralewska, M. Zieliński, M. Pietrowski, W. Przystajko and M. Wojciechowska, Catalysis Today, 2011 176, 263-266.
38 M. Zieliński, I. Tomska-Foralewska, M. Pietrowski, W. Przystajko and M. Wojciechowska, Catalysis Today, 2012, 191, 75-78.

39 M. Zieliński, A. Kiderys, M. Pietrowski, I. Tomska-Foralewska and M. Wojciechowska, Catalysis Communications, 2016, 76, 54-57.

40 S. Célerier, S. Morisset, I. Batonneau-Gener, T. Belin, K. Younes and C. Batiot-Dupeyrat, Applied Catalysis A: General, 2018, 557, 135-144.

41 G. Scholz, C. Stosiek, M. Feist and E. Kemnitz, Eur. J. Inorg. Chem., 2012, 2012, 2337-2340.

42 R. E. O'Neill, L. Vanoye, C. De Bellefon and F. Aiouache, Applied Catalysis B: Environmental, 2014, 144, 46-56.

43 A. A. Rywak, J. M. Burlitch and T. M. Loehr, Chem. Mater., $1995,7,2028-2038$

44 Y. Diao, W. P. Walawender, C. M. Sorensen, K. J. Klabunde and T. Ricker, Chem. Mater., 2002, 14, 362-368.

45 S. Wuttke, A. Vimont, J.-C. Lavalley, M. Daturi and E. Kemnitz, J. Phys. Chem. C, 2010, 114, 5113-5120.

46 I. Agirrezabal-Telleria, Y. Guo, F. Hemmann, P. L. Arias and E. Kemnitz, Catal. Sci. Technol., 2014, 4, 1357-1368.

47 F. Richard, S. Célérier, M. Vilette, J.-D. Comparot and V. Montouillout, Applied Catalysis B: Environmental, 2014, 152153, 241-249.

48 C. Lahousse, A. Aboulayt, F. Maugé, J. Bachelier and J. C. Lavalley, Journal of Molecular Catalysis, 1993, 84, 283-297.

49 C. Lahousse, F. Maugé, J. Bachelier and J.-C. Lavalley, J. Chem. Soc., Faraday Trans., 1995, 91, 2907-2912.

50 J. Szanyi and J. H. Kwak, Phys. Chem. Chem. Phys., 2014, 16, 15117-15125.

51 K. I. Hadjiivanov and G. N. Vayssilov, in Advances in Catalysis, Academic Press, 2002, vol. 47, pp. 307-511.

52 T. Krahl, A. Vimont, G. Eltanany, M. Daturi and E. Kemnitz, J. Phys. Chem. C, 2007, 111, 18317-18325.

53 A. Astruc, C. Cochon, S. Dessources, S. Célérier and S. Brunet, Applied Catalysis A: General, 2013, 453, 20-27.

54 S. Wuttke, S. M. Coman, J. Kröhnert, F. C. Jentoft and E. Kemnitz, Catalysis Today, 2010, 152, 2-10.

55 M. Akimoto and I. G. D. Lana, Journal of Catalysis, 1980, 62 84-93.

56 H. Hattori, Applied Catalysis A: General, 2015, 504, 103-109. 